\title{
The Open-Air School Typology in the Milanese Experience: The Trotter and the Rinnovata Pizzigoni
}

\author{
Enrico Bordogna
}

\begin{abstract}
This text investigates the particular typology of open-air schools in Milanese architecture in relation to similar experiences in modern European architecture from Unification until the 1930s.
\end{abstract}

Keywords Open-air school $\cdot$ Typology $\cdot$ Trotter $\cdot$ Rinnovata Pizzigoni

The first three decades of the twentieth century in Milan saw the appearance of a typological alternative to traditional school building of great importance, which was the fruit of two converging trends: on the one hand, the strict adherence of the building structure to an innovative pedagogical concept, specifically the one trialled since 1911 by the teacher Giuseppina Pizzigoni; on the other hand, a reference to the experience, in many ways similar, of open-air schools in the Central-European and North American traditions. This was the Renewed Elementary School at Ghisolfathe Rinnovata Pizzigoni-and the open-air Trotter School at Turro, both designed and built during the First World War and both located, perhaps not by chance, in two very characteristic areas at the outskirts of old Milan, and which became constitutive elements of their respective cultural and settlement identities.

If in the Rinnovata at Ghisolfa what prevailed was certainly the pedagogical and educational spirit, in the Trotter school at Turro what was more marked was the hygienic-health aspect accompanied by an anti-urban reaction against the ills of the contemporary city. In both designs, however, there is an active educational imprint, founded on direct experience and observation, on the relationship with nature, on the value of socialization, manual activities and work, marked, albeit with some significant architectural and compositional differences, by an analogous typological system, with only one floor above ground, filled with collective environments and classrooms for special activities, and the regular classrooms opening directly onto the green spaces, which are in turn equipped with workshops, animal pens, orchards, glasshouses, and a swimming pool.

\footnotetext{
E. Bordogna ( $\varangle)$

Architecture, Built Environment and Construction Engineering-ABC Department,

Politecnico di Milano, Milan, Italy

e-mail: enrico.bordogna@polimi.it 
The origin of the school at Ghisolfa dates back to 1911, while the Trotter Schoolinto the bargain directly influenced by the Rinnovata-was a project of the 1918 Giunta Caldara; however, both acquired their definitive typological and constructive form between 1925 and 1927.

The Rinnovata at Ghisolfa represents a wholly original case in the panorama of the Milanese school typology, the first, and perhaps only example, in which an innovative pedagogical programme, that of Giuseppina Pizzigoni, became the direct matrix of its typological conformation.

In 1911, a manifesto was published by the Municipality of Milan notifying the citizenship that "in two sections of the first class at the Ghisolfa school the experimental method proposed by the Committee for the Rinnovata will be applied, with the approval and backing of the school authorities, the City Hall, and the Government. There are 60 places, 30 for girls and 30 for boys. In these two sections, the timetable will run from 9 am to $5 \mathrm{pm}$, with a two-hour break spent at school to eat and rest. The curriculum will be the same as at other schools but taught using a different method". ${ }^{1}$ This different method was the experimental one advocated by Pizzigoni, whose fundamental elements can be summarized as follows: full-time education with lunch taken at school; classes with a maximum of 30 pupils against the 50-70 permitted by the regulations; ample room allocated to physical education, outdoor activities, and extra-school excursions; "coeducation", that is, the introduction of mixed-sex classes; faithfulness to the ministerial programmes, but taught according to a method which gave prime importance to observation and the children' direct experience.

When it opened, the Rinnovata did not have its own premises but was housed in four Döcker pavilions (a sort of prefabricated hut of the time) at the municipal primary school of Ghisolfa, situated "on the northern boundary of Milan between Bovisa, Cagnola and Ghisolfa [where] there are the council housing estates of the Ente Autonomo and [where] vast meadows and fields and orchards still lie". ${ }^{2}$ Pizzigoni's reference is to the famous IACP neighbourhoods "Mac Mahon", "Cialdini", "Villapizzone", and "Campo dei Fiori", built between 1909 and 1919 and still existing (except for "Campo dei Fiori", which was demolished in the 1960s).

Of the various components which made up the Pizzigoni method, manual work was the fundamental characterizing element. This was "a tool of the method, a coefficient of education [...] The manual work that we introduce in school will give the pupils dexterity and will contribute powerfully to the wealth of ideas around things, to the richness of individual vocabulary, and instil the concept that study, that life itself, is work". 3

This method fitted into the more general movement which in the second half of the nineteenth century fought for a radical reform of teaching and learning, and which,

\footnotetext{
${ }^{1}$ In P. F. Nicoli, Storia della Scuola Rinnovata secondo il metodo sperimentale, Ufficio Propaganda Opera Pizzigoni, Milan 1947, p. 32.

${ }^{2}$ In G. Pizzigoni, La Scuola Rinnovata, Conferenza tenuta alla Regia Società Italiana di Igiene il 6 marzo 1914, in Nicoli, op. cit., pp. 41-42.

${ }^{3}$ In G. Pizzigoni, Conferenza tenuta nell'Aula Magna del Ginnasio Beccaria, marzo 1911, in Nicoli, op. cit., pp. 26-28.
} 
on the threshold of the new century, came out of the closet of theoretical debate in order to compete in a series of concrete experiments in some countries of Central Europe and North America: from the Landerziehungsheime (houses of education in the country) and the Waldschulen (schools in the forest) in Germany, the open-air schools in Britain, the Écoles des Roches (schools of the rocks) in France, and the numerous active schools inspired by the teachings of J. Dewey in America.

In the city of Milan itself in those years initiatives sprang up that were close to Pizzigoni's ideas, such as the Per la Scuola association, founded in 1907 by a group of scholars and benefactors and, especially, the Società Umanitaria (Humane Society), whose many activities concerning community education greatly aroused Pizzigoni's interest. ${ }^{4}$ However, her own programme differed from these Milanese initiatives and from most of the international experiments in so far as it was not aimed at special categories (frail children and those with TB at the open-air schools rather than the workers at the Umanitaria trade schools) but presented itself as a model for teaching healthy children from state primary schools, which would have needed radically reforming to fit with the experimental method.

Naturally, her scheme also required a profound transformation of the traditional school building. In fact, right from the first draft of her programme in 1907, Pizzigoni envisaged a typology commensurate with the needs of the new method, until, in 1914, with the help of the engineer Erminio Valverti, a member of the Rinnovata School Committee, she herself published a methodical project for a school of 400 pupils. ${ }^{5}$

"By an environment suitable for a new school," commented Pizzigoni, "I mean firstly a simple block whose architectural lines and furnishings apply a severe and serene concept to the house for study, which will serve to facilitate each scholastic task and educate the aesthetic sense. It must be provided with capacious classrooms, cheered by large French windows through which the light enters in torrents and the children can rapidly and frequently exit from; a well-furnished kitchen, a refectory, lavatories, showers, and decent healthcare services. There must also be a room for projections, one for music, for work, for a museum [...]. The building is located in the middle of grounds that offer a playing field, a garden and a kitchen garden [...]. The garden should have a henhouse, a rabbit hutch, a pool with fish, an apiary, and a cage with birds". 6

The project designed by Valverti is an almost diagrammatic version of this description of Pizzigoni. When, in 1924, the Administration guided by Luigi Mangiagalli allocated a new seat to the Rinnovata between the Northern Railway and Via Artieri, Via Monte Ceneri, Via General Govone (today Castellino da Castello), Amerigo Belloni of the Municipal Technical Office merely copied Valverti's project, adapting

\footnotetext{
${ }^{4}$ The relationship of mutual interest between the Società Umanitaria and Pizzigoni was confirmed by the conference she held at a major convention on popular education, organized by the Umanitaria at its headquarters in October 1916, on the invitation of its Director, Augusto Osimo. See Nicoli, op. cit., p. 92.

${ }^{5}$ See G. Pizzigoni, La Scuola Elementare Rinnovata secondo il metodo sperimentale, Milan, Paravia, undated (but 1914), pp. 22-23, and p. 39.

${ }^{6}$ Ibid, pp. 36-37.
} 
it to the selected lot of approximately $20,000 \mathrm{~m}^{2}$. The result was a simple building with only one floor above ground (except for the entranceway) with an L-shaped plan.

On the ground floor, besides the offices and classrooms (29) for regular teaching, each equipped with changing rooms and with direct access to the garden, we find "the workshops (for printers, engravers, blacksmiths, mechanics, shoemakers, and carpenters, all grouped together at the northern end of the building so as not to cause disturbance to the teaching that will take place simultaneously in the classrooms), the gym, the theatre, the room for projections, the refectory, and the classrooms for drawing and sculpting [...]. On the first floor (above the entranceway) are arranged the school museum and the boys' and girls' work rooms, for music, typing [...]. In part of the area lying along Via Artieri, there is the school farm (with two pavilions: one for agriculture lessons and the other for the animal pens and the homesteader's dwelling), playing fields for the pupils' recreation and the indoor swimming pool". 7 The architectural forms, as an attentive observer of the time wrote, are "those characteristic of the Lombard farmstead" 8 ; or, more accurately, those copied from mediaeval Lombard architecture, as Boito might have said, selected by the architects of Eclecticism for buildings to meet the new social needs (Figs. 1-2-3-4-5).

If educational and pedagogical reforms fundamentally underlay the Renewed Elementary School at Ghisolfa, the intent and criteria that govern the idea of an open-air school in general are predominantly healthcare and hygiene issues. In fact, the idea of the open-air school also brings together a widespread sensitivity, of a generically humanitarian and progressive stamp, identifying in the rejection of the big city and the return to nature the antidote to the evils of contemporary urban planning, generically identified as the ultimate cause of the violent conflicts induced by industrialization (slums, tuberculosis, infantile frailty, alcoholism, etc.).

Already by 1910, in the second issue of the magazine Le case popolari e le città giardino an editorial appeared in favour of open-air schools with documentation on the one created in 1907 in Letchworth, the first garden city in the UK, and with the news that also in Milan a public announcement had been made of the project "to establish for frail children an open-air school similar to the German Waldeschulen and open-air British schools". 9

And in 1912, in a pamphlet entitled La Scuola all'aperto, written by Prof. Carlo A. Mor, one of the main leaders of the Per la Scuola association, after a series of considerations on the "social scourge, the fearsome plague" of tuberculosis, we read: "So it is not about correcting and modifying all the current trends of the city's municipal schools where smart Administrations_-as in Milan-have become zealous and strict interpreters of hygiene in school, it is, instead, about creating and bringing

\footnotetext{
${ }^{7}$ In A. Belloni, Relazione tecnica al Progetto della Nuova Sede della Scuola Elementare Rinnovata da erigersi in Via General Govone, 3 giugno 1924, Archivio Storico Comunale, Fondo Finanze-Beni Comunali, cart. 206, manuscript.

${ }^{8}$ In L. L. Secchi, Edifici scolastici italiani primari e secondari, Hoepli, Milan 1927, p. 216.

${ }^{9}$ In the editorial, Le scuole all'aperto, in "Le Case Popolari e le Città-Giardino", year 1, no. 2, 1910 , pp. 59-60.
} 

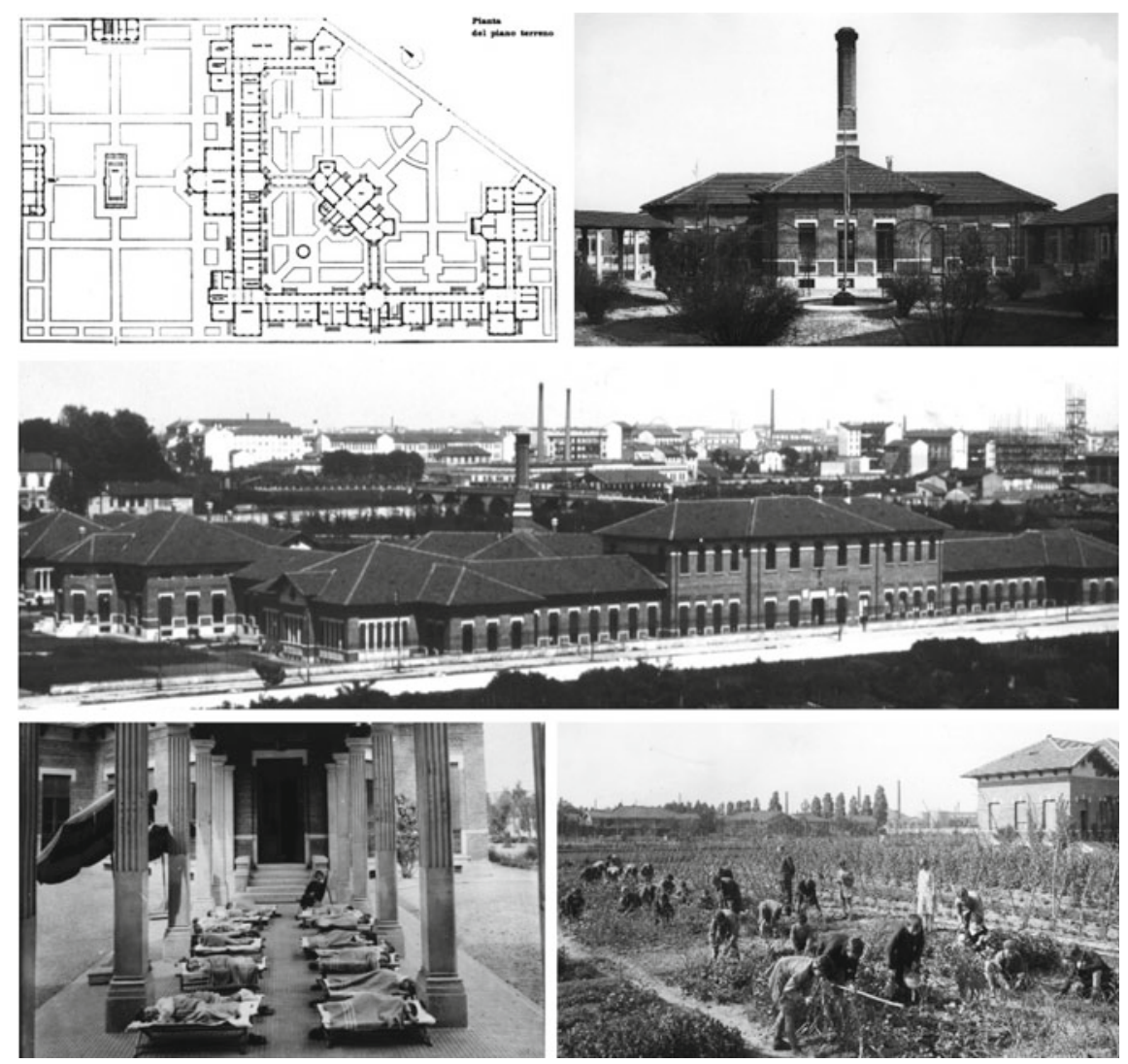

Figs. 1-2-3-4-5 A. Belloni (Municipal Technical Office), Pizzigoni Renovated Elementary School in Via General Govone (now Via Castellino da Castello), Milan, 1924-1927: ground floor plan and views; educational and recreational activities in some images of the mid-thirties

order to what, methodically, does not exist. It is about establishing special schools for frail children". ${ }^{10}$

Among these initiatives, the "Umberto di Savoia" open-air school at the Trotter Park at Turro represented the most important achievement, according to contemporaries, the greatest in Italy and among the greatest in Europe. It sits in the old harness-racing field between Via Monza and Via Padova; an area of approximately $128,000 \mathrm{~m}^{2}$ (partly occupied by the racing tracks, the stand, the stables, and the services, but otherwise arranged inside large, densely wooded meadows) which the Municipality of the Giunta Caldara acquired in 1919 from the Società del Trotter.

The project, designed by the engineer G. Folli of the Municipal Technical Office in 1919 , is of great interest not only due to the scope of the intervention, which occupies

\footnotetext{
${ }^{10}$ In C. A. Mor, La Scuola all'aperto e i criteri informativi di assistenza educativa, Tip. A. Antonini \& C., Milan 1912, p. 12.
} 
the whole of the large enclosure but also for the typological layout adopted. In fact, contrary to all the previous traditions, the choice was that of a school in pavilions scattered across the green areas. The pavilions for the classrooms number 12, have only one storey, and are raised $1.20 \mathrm{~m}$ above the ground. Each pavilion includes four classrooms to take 35 pupils and is formed by two double blocks joined at the rear by a veranda which functions as an indoor recreation area and refectory; at the ends of the veranda are rooms for the doctor, teachers, and the janitor. In a smaller pavilion at the back, connected by a canopy, are the lavatories and the showers. The four classrooms are arranged at the corners so as to enjoy double illumination and direct access to the garden through independent stairs.

Given the high number of pupils (about 1700), the school is divided into three sections with four pavilions each. Each section is equipped with a building in a central position to house the general services of the kitchen, head office, healthcare management, teaching museum, library, and so on. Of the three buildings for general services, two would be new-builds and the third a conversion of the old Trotter buildings overlooking Via Padova. Completing the school's amenities are a wide range of facilities: "In the central part of the area enclosed by the track, we have designed several fields for games and physical education, such as lawn tennis, skating, and ice skating in winter, football, bowling and croquet and finally a large swimmingpool". ${ }^{11}$ Also the racetrack was kept, "because it will be an excellent asset for sports since it can serve for exercises of walking or running and cycling [...]. It will also serve as a place for heliotherapeutic cures during the summer months, as was already practised last year for the summer camp established for frail children with a positive outcome and that we believe will continue operating every year during the school summer holidays". ${ }^{12}$ Then, finally two cinemas, one in a new pavilion, the other obtained from the old Trotter buildings on Via Padova, complete the complex.

The architectural appearance of the school is deliberately low-key, recalling "the type of constructions of a Swiss chalet, with pediments, gutters and wooden cladding and with a sober painted decoration and friezes along the walls". A deliberate sobriety, it is stated shortly afterwards, dictated by the consideration that "the character of these buildings distributed in the midst of green fields and heavily wooded is not such as to require decorative displays". ${ }^{13}$

The project for the large Trotter school was an initiative of the Socialist Giunta Caldara, which by 1920 had already begun the works. These were protracted in subsequent years under the so-called national block Giunta, which governed between 1922 and 1926 (fascists, liberals, and populists in which the councillor for urban planning was the liberal Cesare Chiodi).

In the course of the work the original project underwent some marginal changes, but above all it was enriched with new facilities: the Casa dei Bambini for children of pre-school age (designed by the engineer L. Beretta in keeping with the school's

\footnotetext{
${ }^{11}$ In G. Folli, Progetto di una scuola all'aperto nel recinto del Trotter nel Riparto di Turro. Relazione tecnica, 30 luglio 1919, Archivio Storico Comunale, Fondo Finanze - Beni Comunali, Cartella 208, typed manuscript, p. 2.

${ }^{12}$ Ibid.

${ }^{13}$ Idem, p. 4.
} 
pavilions), the Casa del Sole boarding school, housing 160 beds to accommodate the children of parents suffering from TB, two gyms, and a small church.

By 1928, the works were almost complete, so that in the August issue of the magazine "Milano", which punctually documented the doings of the city administration, a richly illustrated and legitimately eulogistic special was included on the new school which rises "on the old field for harness racing, salvaged providentially from the Municipality by private speculation and designed to accommodate the largest and perhaps most beautiful open-air school in Europe". ${ }^{14}$ The new complex, whose many features were listed (the school itself, of an agrarian type and therefore with flowerbeds, gardens, orchards, animal pens, chicken runs, etc.; the Casa Montessoriana for young children; the Casa del Sole boarding school; the summer camp, attended by 2400 frail children selected from all the city's schools) was presented as an alternative to the traditional school system. In fact, "our primary schools, even the most beautiful and the most modern, are inevitable 'school barracks', as crowded and buzzing as hives. The interminable corridors, the classrooms that do not always see sunlight, the closed courtyards [...]. Hence, in reaction to these indoor environments, came the need to create an antidote to what might be defined as the painful school phenomenon of urbanization". 15

Thus the Trotter school at Turro and the Rinnovata Pizzigoni elementary school at Bovisa, even with the differences observed earlier, represented a fundamental innovation in the panorama of Milanese schools in the first decades of the century, a turning point among schools created by positivist Eclecticism and those that were the fruit of subsequent rationalist research. Indeed, together, they are respectably on par with the best-known examples produced a few years later, between the end of the Twenties and the Thirties, by modern European architecture, whether the so-called "redbrick schools", such as those of Wilhelm Dudok and Fritz Schumacher in Hilversum and Hamburg, respectively, which still interpreted the school as a monumental element in the construction of a city, or the so-called "experimental schools", like those created by Ernst May and Martin Elsässer in Frankfurt, or by Otto Haesler in Celle, or again by Bruno and Max Taut in Berlin, which represented the most limpid outcome of a long in-depth analysis of the school organism, broken down into the individual functions and elements of which the educational mechanism is made. All these schools, according to the interpretation of Julius Posener, ${ }^{16}$ represent a divergence in the European panorama of the Thirties between a "pole of tradition", still attentive to the urban value of the school building as an element in the construction of a city, and a "pole of radical reformers", which, although welcoming even extremely diversified positions among its members, identifies itself with the common commitment to functionally remove the inner device.

\footnotetext{
${ }^{14}$ In L. Clerle, La scuola all'aperto "Umberto di Savoia", la "Casa del Sole”, in "Milano", year XLIV, no. 8, August 1928, p. 33.

${ }^{15}$ Ibid. On the open-air Trotter school complex, see also L. L. Secchi, op. cit., pp. 132-133, pp. 155158, pp. 165-166.

${ }^{16}$ See J. Posener, Écoles allemandes, in Les écoles à l'étranger, special issue of "L'Architecture d'Aujourd'hui", no. 2, March 1933.
} 


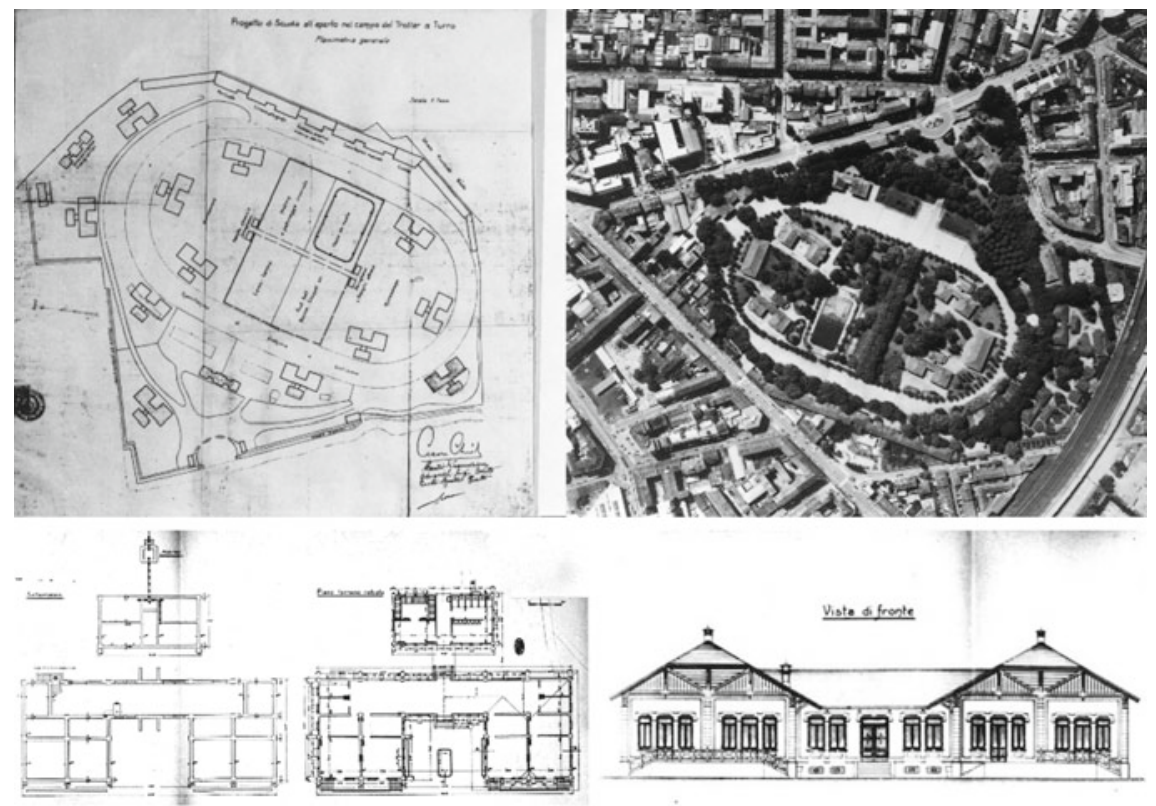

Figs. 6-7 Ing. G. Folli (Municipal Technical Office), Open-air school "Umberto di Savoia" at Trotter in Turro, Milan, 1918-1927: general plan, zenithal view of 1972, plans of the basement and of the mezzanine of a pavilion-type of four classrooms and front and side elevation

Equally relevant would then be the comparison with the open-air schools created by Eugène Beaudouin and Marcel Lods, with the decisive technological contribution of Jean Prouvé, in the Parisian suburb of Suresnes, or the one, singular in its being developed height-wise, by Johannes Duiker in the courtyard of an urban block on the Cliostraat of South Amsterdam, or even that by Neutra for the Rush City Reformed in the USA.

Still today, albeit in changed contextual conditions, the Trotter and Rinnovata Pizzigoni schools actively fulfil their function, as a testimony to the value of typological research carried out almost a century ago, and to their congruency with the cultural and settlement identity of the neighbourhoods in which they were developed and have operated (Figs. 6-7, 8-9-10, 11-12 and 13). ${ }^{17}$

\footnotetext{
${ }^{17}$ On the history of the scholastic typology in Milanese architecture cfr. also: E. Bordogna, Radici tipiche dell'architettura scolastica a Milano, in «Hinterland», n. 17, marzo 1981, pp. 68-79; Idem, Sperimentazione didattica e innovazione tipologica in un quartiere industriale: la Bovisa e la Rinnovata Pizzigoni, in G. Fiorese, M. Deimichei (a cura di), Milano Zona Sette: Bovisa Dergano, Comune di Milano-Clup, Milano 1984, pp. 61-66; Idem, Alle origini dell'architettura scolastica milanese, in G. Fiorese (a cura di), Milano Zona Due. Centro Direzionale, Greco, Zara, Comune di Milano, 1987, pp. 115-119; Idem, La scuola all'aperto del Trotter a Turro, Milano: innovazione tipologica e dettato pedagogico, in «Edilizia scolastica e culturale», Le Monnier, Firenze, n. 5, maggio-agosto 1987, pp. 85-94.
} 

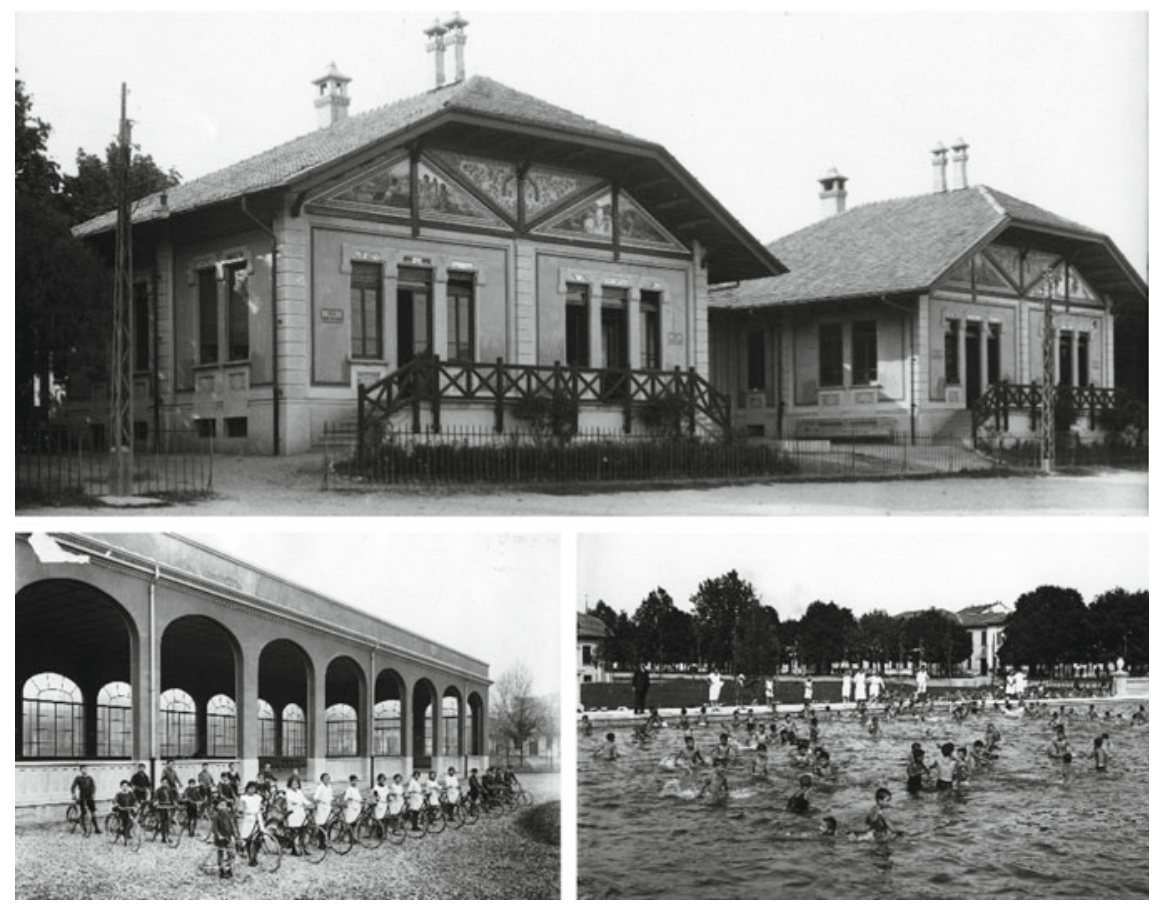

Figs. 8-9-10 Ing. G. Folli (Municipal Technical Office), "Umberto di Savoia" open-air school at Trotter in Turro, Milan, 1918-1927: view of a type pavilion of four classrooms, view of the gym and view of the pool
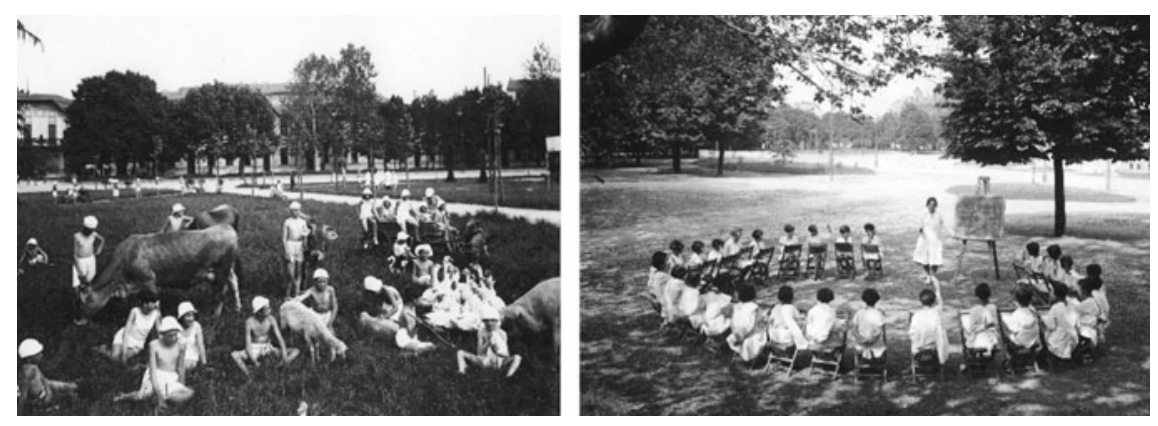

Figs. 11-12 Ing. G. Folli (Municipal Technical Office), "Umberto di Savoia" open-air school at Trotter in Turro, Milan, 1918-1927: educational and recreational activities in some images from the 1920 s and 1930 s 

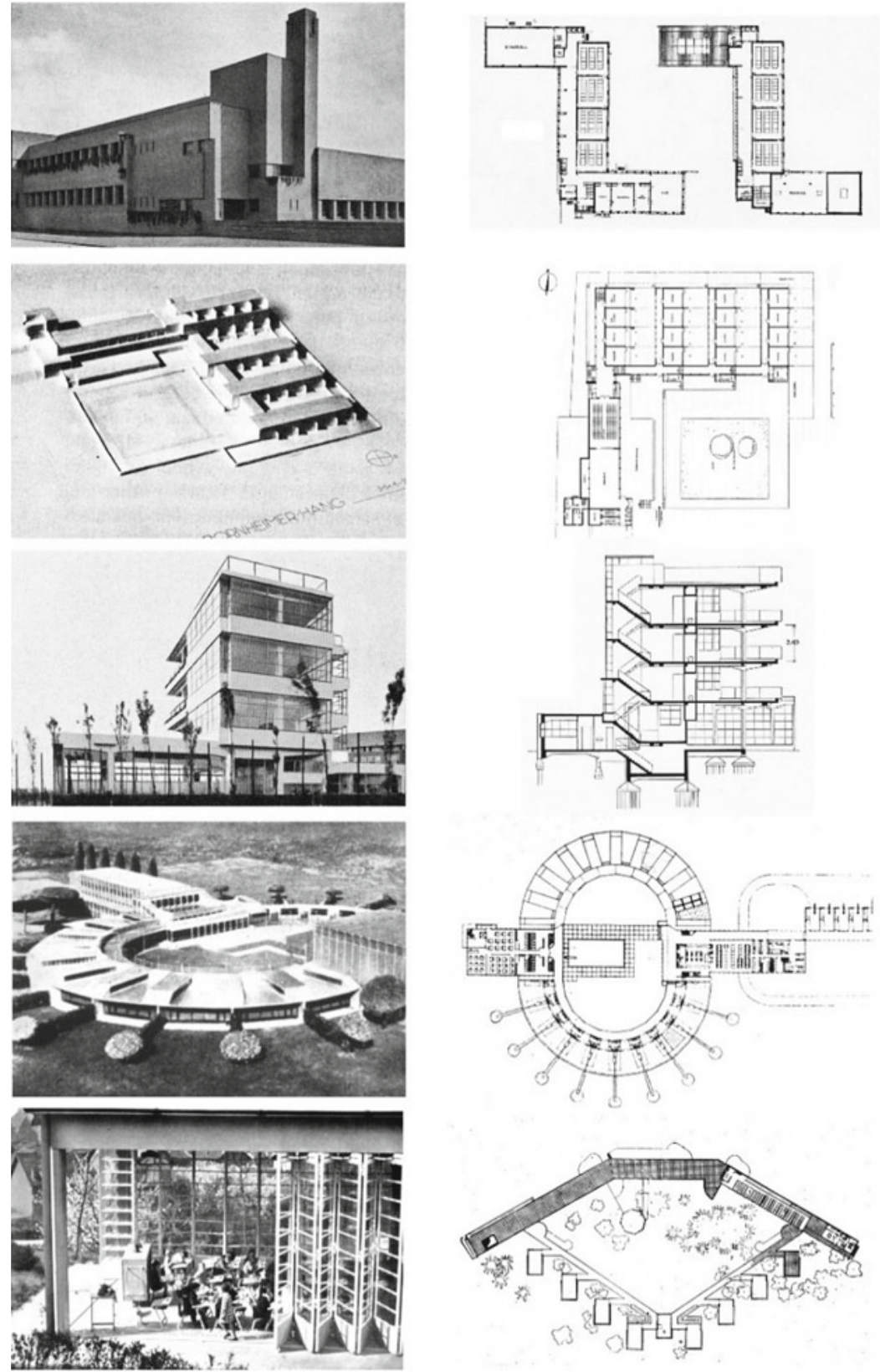

Fig. 13 W. M. Dudok, Elementary School “Dr. Bavinck”, Hilversum, Holland, 1921: plants and view; E. May, with M. Elsaesser, Reformed Elementary School in the Siedlung Bornheimer Hang, Frankfurt am Main, 1928: plan and model; J. Duiker, Open air school on the Cliostraat, Amsterdam, 1932: view and section; R. J. Neutra, open-air circular school for the Rush City Reformed, 1928: plan and model; E. Beaudouin and M. Lods, with J. Prouvé, Open air school in Suresnes, Paris, 1934: plan and view of a classroom 
Open Access This chapter is licensed under the terms of the Creative Commons Attribution 4.0 International License (http://creativecommons.org/licenses/by/4.0/), which permits use, sharing, adaptation, distribution and reproduction in any medium or format, as long as you give appropriate credit to the original author(s) and the source, provide a link to the Creative Commons license and indicate if changes were made.

The images or other third party material in this chapter are included in the chapter's Creative Commons license, unless indicated otherwise in a credit line to the material. If material is not included in the chapter's Creative Commons license and your intended use is not permitted by statutory regulation or exceeds the permitted use, you will need to obtain permission directly from the copyright holder.

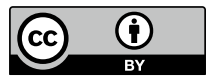

